\title{
THE EFFECT OF LIGHT ON SILVER CHLORIDE IN CHEMICAL ANALYSES
}

\author{
By G. E. F. Lundell and J. I. Hoffman
}

\begin{abstract}
The experiments described in this paper show the direction and magnitude of the errors that may be expected in analytical work if silver chloride is not protected from light. Exposure to light during precipitation always causes positive errors if silver is in excess, and negative errors if hydrochloric acid is in excess. Exposure of dry precipitates has very little effect. The error, if any, is negative and becomes greater if the dried precipitate is moistened before exposure or if the precipitate is exposed before drying. Exposure to light probably produces a mixture of metallic silver and silver chloride.
\end{abstract}

\section{CONTENTS}

I. Introduction

II. Experimental

1. Standard solutions used

2. Precipitation of silver chloride

3. Exposure to light.

III. Discussion of results

IV. Examination of the precipitates formed under the influence of light.-

\section{INTRODUCTION}

In practically all analytical procedures dealing with the precipitation of silver chloride the analyst is cautioned to protect the precipitate from light. No information appears to be available, however, in regard to the magnitude of the errors caused by the neglect of such protection. The determination of silver or chlorine as silver chloride enters into so many fundamental analyses that it seemed advisable to study and record the effect of light. The experiments were performed from the standpoint of analytical chemistry rather than photochemistry.

\section{EXPERIMENTAL}

\section{STANDARD SOLUTIONS USED}

A dilute solution of hydrochloric acid was standardized in three ways: (1) By carefully precipitating and weighing silver chloride with every protection against light; (2) by titrating against a solution of sodium hydroxide which had been standardized $(a)$ against the Bureau of Standards Standard Acid Potassium Phthalate No. 84, and (b) against the Bureau of Standards Standard Benzoic Acid No. 39b. The results of the three methods of standardization agreed within 1 part in 4,000 . 
Two solutions containing silver were used. The one was prepared by using as a standard, silver phosphate made according to the directions of Baxter and Jones ${ }^{1}$ in their work on the atomic weight of phosphorus. The other was a $0.2 N$ solution of silver nitrate standardized by precipitating the silver as chloride with every protection against the influence of light. Weight burettes were used throughout, except for measuring the solution of silver nitrate in experiments 1 to 8 , inclusive, Table 1 . In these experiments carefully calibrated volume pipettes were used.

\section{PRECIPITATION OF SILVER CHLORIDE}

Two distinct series of precipitations were made. In both of these the conditions usually prescribed for precipitating silver chloride were maintained with the exception of the exposure to light. In the one series (Nos. 1 to 15 in Table 1) the silver in measured portions of the standard solutions was precipitated with such an excess of hydrochloric acid that the solution contained finally $1 \mathrm{ml}$ of hydrochloric acid (specific gravity 1.19) per $100 \mathrm{ml}$ of solution. In the other series chlorine was precipitated from weighed portions of the standard solution of hydrochloric acid by adding a few drops of nitric acid and an excess of silver nitrate in the amounts shown in Table 1. In all cases the precipitant was added slowly and with constant stirring. The final volume of the solutions was $200 \mathrm{ml}$, and all of the precipitates, excepting those in experiments $12,13,14$, and 15 in Table 1, were coagulated by digesting on the steam bath for 15 to 30 minutes before they were exposed to light. The precipitates were caught in platinum crucibles fitted with platinum pads (Munroe crucibles). Those formed in the presence of an excess of hydrochloric acid were washed with a 1 per cent solution of hydrochloric acid (1 mi of $\mathrm{HCl}$, specific gravity 1.19 , per $100 \mathrm{ml}$ of wash solution); those formed in the presence of an excess of silver nitrate were washed with a 0.5 per cent solution of nitric acid $\left(1 \mathrm{ml}\right.$ of $\mathrm{HNO}_{3}$, specific gravity 1.42 , per $200 \mathrm{ml}$ of wash solution). The washed precipitates were then dried at $130^{\circ}$ to $140^{\circ} \mathrm{C}$. and weighed.

\section{EXPOSURE TO LIGHT}

The results shown in Table 1 were obtained by exposing the precipitates in the precipitating medium in Pyrex beakers to light as indicated. The beakers exposed to north light were placed next to the north wall of the laboratory in such a position that no direct or reflected rays of the sun could reach them. Those exposed to artificial light were placed about $40 \mathrm{~cm}$ from an inclosed type carbon arc light, operated at 200 volts d. c. at 13 amperes, described by Walker and Hickson. ${ }^{2}$

1 G. P. Baxter and G. Jones, J. Am. Chem. Soc., 32, p. 298; 1910.

2 P. H. Walker and E. F. Hickson, Ind. \& Eng. Chem., 20, p. 591; 1928. 
TABLE 1.-Effect of light on silver chloride in the precipitating medium

\begin{tabular}{|c|c|c|c|c|c|}
\hline \multirow{2}{*}{ No. } & \multicolumn{3}{|c|}{$A g C I$} & \multirow{2}{*}{ Method of precipitation } & \multirow{2}{*}{ Degree and kind of exposure } \\
\hline & $\begin{array}{l}\text { Calcu- } \\
\text { lated }\end{array}$ & Found & Error & & \\
\hline 1 & $\stackrel{g}{g}+3971$ & $\stackrel{g}{g}+3948$ & $-0 . \stackrel{g}{0023}$ & $\begin{array}{l}\text { Standard solution of } \mathrm{AgNO}_{3} \text {, treated } \\
\text { with an excess of } \mathrm{HCl} \text {. }\end{array}$ & $\begin{array}{l}7 \text { hours north light, occasional } \\
\text { stirring. }\end{array}$ \\
\hline 2 & 1.3348 & 1. 3216 & -.0132 & & $\begin{array}{l}72 \text { hours north light, } 7 \text { hours direct } \\
\text { sunlight, occasional stirring. }\end{array}$ \\
\hline $\begin{array}{l}3 \\
4\end{array}$ & $\begin{array}{l}.8293 \\
1.3971\end{array}$ & $\begin{array}{r}.8176 \\
1.3932\end{array}$ & $\begin{array}{l}-.0117 \\
-.0039\end{array}$ & 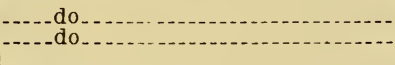 & $\begin{array}{l}\text { Do. } \\
2 \text { hours direct dim sunlight, con- } \\
\text { stant stirring. }\end{array}$ \\
\hline 15 & .6985 & .6947 & -.0038 & - do do & Do. \\
\hline 6 & 1. 3971 & 1.3915 & -.0056 & & $\begin{array}{l}2 \text { hours direct dim sunlight, no } \\
\text { stirring. }\end{array}$ \\
\hline $\begin{array}{r}17 \\
8\end{array}$ & $\begin{array}{r}.6985 \\
1.3971\end{array}$ & $\begin{array}{r}.6938 \\
1.3883\end{array}$ & $\begin{array}{l}-.0047 \\
-.0088\end{array}$ & . do $_{-}$ & $\begin{array}{l}5 \text { hours arc light, occasional stir- } \\
\text { ring. }\end{array}$ \\
\hline 29 & .7859 & .7851 & -.0008 & & $\begin{array}{l}2 \text { hours in bright laboratory, no } \\
\text { direct or reflected sur light. } \\
\text { occasional stirring. }\end{array}$ \\
\hline $\begin{array}{l}210 \\
211\end{array}$ & $\begin{array}{l}.6961 \\
.0279\end{array}$ & .6954 & $\begin{array}{l}-.0007 \\
-.0001\end{array}$ & ... do & $\begin{array}{l}\text { Do. } \\
\text { Do. }\end{array}$ \\
\hline${ }^{3} 12$ & .0028 & .0022 & -.0006 & $\begin{array}{l}\text { Very faint excess of } \mathrm{HCl} \text { during time } \\
\text { of exposure to light. Acid concen- } \\
\text { tration raised to } 1 \text { per cent by } \\
\text { volume before filtration. }\end{array}$ & $\begin{array}{l}3 \text { hours dim sunlight }+20 \text { hours are } \\
\text { light. }\end{array}$ \\
\hline 313 & .0028 & .0022 & -.0006 & 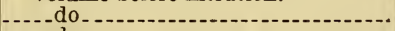 & Do. \\
\hline $\begin{array}{l}314 \\
315\end{array}$ & $\begin{array}{l}.0028 \\
.0028\end{array}$ & $\begin{array}{l}.0029 \\
.0028\end{array}$ & $\begin{array}{r}+.0001 \\
.0000\end{array}$ & $\begin{array}{ll}-1 \\
-\end{array}$ & $\begin{array}{l}\text { Protected from all light. } \\
\text { Do. }\end{array}$ \\
\hline 16 & .6683 & .6717 & +.0034 & $\begin{array}{l}\text { Standard solution of } \mathrm{HCl} \text { treated } \\
\text { with } 100 \text { per cent excess of } \mathrm{AgNO}_{3} \text {. }\end{array}$ & $\begin{array}{l}7 \text { hours north light, occasional } \\
\text { stirring. }\end{array}$ \\
\hline 17 & .6669 & .6751 & +.0082 & whener & $\begin{array}{l}2 \text { hours direct dim sunlight, con- } \\
\text { stant stirring. }\end{array}$ \\
\hline $\begin{array}{r}118 \\
19\end{array}$ & $\begin{array}{l}.7429 \\
.7683\end{array}$ & $\begin{array}{l}.7554 \\
.7771\end{array}$ & $\begin{array}{l}+.0125 \\
+.0088\end{array}$ & $\begin{array}{l}\text { do } \\
\text { do }\end{array}$ & 2 hours direct dim sunlight, no \\
\hline $\begin{array}{rl}1 & 20 \\
21 & -1\end{array}$ & $\begin{array}{l}.6410 \\
.7921\end{array}$ & $\begin{array}{l}.6476 \\
.8271\end{array}$ & $\begin{array}{l}+.0066 \\
+.0350\end{array}$ & -. do & $\begin{array}{l}\text { Do. } \\
5 \text { hours arc light, occasional stirring. }\end{array}$ \\
\hline 22 & 1. 1967 & 1. 2506 & +.0539 & $\begin{array}{l}\text { Standard solution of } \mathrm{HCl} \text { treated } \\
\text { with } 1 \text { to } 3 \mathrm{ml} \text { of a } 0.2 \mathrm{~N} \text { solution } \\
\text { of } \mathrm{AgNO}_{3} \text { in excess. }\end{array}$ & $\begin{array}{l}72 \text { hours north light }+7 \text { hours direct } \\
\text { sunlight, occasional stirring. }\end{array}$ \\
\hline 23 & 1. 2903 & 1. 3179 & +.0276 & do & $\begin{array}{l}5 \text { hours direct sunlight, occasional } \\
\text { stirring. }\end{array}$ \\
\hline 24 & 1. 2762 & 1.3097 & +.0335 & do & Do. \\
\hline${ }^{2} 25$ & .5184 & .5194 & +.0010 & do & $\begin{array}{l}2 \text { hours in bright laboratory, no } \\
\text { direct or reflected sunlight, } \\
\text { occasional stirring. } \\
\text { Do. }\end{array}$ \\
\hline & .0030 & .5106 & 7.0010 & & Do. \\
\hline
\end{tabular}

1 The exposure of Nos. $5,7,18$, and 20 was exactly the same.

2 Results Nos. 9, 10,11,25, and 26 were obtained by the use of weight burettes, and the figures given in the "calculated" column were obtained under exactly the same conditions as those in the "found" column, excepting that those in the "calculated" column were protected from all light, while those in the "found" column were exposed as indicated.

${ }^{3}$ Nos. 14 and 15 received exactly the same treatment as Nos. 12 and 13 excepting the exposure to light. Total loss of chlorine in Nos. 12 and 13 would have amounted to $0.0007 \mathrm{~g}$.

The results shown in Table 2 were obtained by exposing the precipitates on perforated platinum crucibles fitted with platinum pads. The sources of light were the same as described in the previous paragraph.

$$
84789^{\circ}-29-8
$$


TABLE 2.-Effect of light on silver chloride in the crucible

\begin{tabular}{|c|c|c|c|c|c|}
\hline No. & $\begin{array}{c}\text { Weight } \\
\text { of nor- } \\
\text { mal } \\
\text { precipi- } \\
\text { tate of } \\
\text { AgCl } \\
\text { before } \\
\text { expo- } \\
\text { sure }\end{array}$ & $\begin{array}{l}\text { Weight } \\
\text { after ex- } \\
\text { posure }\end{array}$ & Error & $\begin{array}{c}\text { Treatment of precipitate before } \\
\text { exposure }\end{array}$ & Degree and kind of exposure \\
\hline $\begin{array}{l}2 \\
3 \\
4 \\
5 \\
6 \\
7\end{array}$ & $\begin{array}{r}g \\
0.7844 \\
.7645 \\
1.2506 \\
.8379 \\
1.3876 \\
.8212 \\
1.6985 \\
1.6985\end{array}$ & $\begin{array}{r}g \\
0.7840 \\
.7642 \\
1.2504 \\
.8378 \\
1.3873 \\
.8203 \\
.6973 \\
.6958\end{array}$ & $\begin{array}{r}g \\
-0.0004 \\
-.0003 \\
-.0002 \\
-.0001 \\
-.0003 \\
-.0009 \\
-.0012 \\
-.0027\end{array}$ & $\begin{array}{l}\text { Dried at } 130^{\circ} \mathrm{C} \\
\\
\text { Dried at } 130^{\circ} \mathrm{C} \text {. and then moistened. } \\
\text { prior to exposure to light. }\end{array}$ & $\begin{array}{l}16 \text { days north light plus } 7 \text { hours } \\
\text { direct sun'ight. } \\
\text { Do. } \\
\text { Do. } \\
2 \text { hours direct sunlight. } \\
\text { Do. } \\
2 \text { hours arc light. } \\
\text { Do. } \\
5 \text { hours arc light. }\end{array}$ \\
\hline
\end{tabular}

1 This represents the weight of $\mathrm{AgCl}$ which should have been obtained under normal conditions as calculated from the standard solution used.

\section{DISCUSSION OF RESULTS}

No analyst would expose silver chloride to an arc light or direct sunlight in determinations of silver or chloride. The results so obtained serve only to show the direction and magnitude of the error. Results Nos. 1, 9, 10,11, 16, 25, and 26, in Table 1, however, are such as might be obtained in ordinary analytical work. Results Nos. 1 and 16 were obtained by precipitating at $5 \mathrm{p}$. m. and allowing the solution to stand unprotected in north light until the next morning at 9 o'clock. The error in both cases is significant. Results Nos. $9,10,11,25$, and 26 were obtained by performing the following operations in a bright laboratory, but not in direct or reflected sunlight. The silver chloride was precipitated in the usual manner, digested on the steam bath for 30 minutes, and set aside for one hour. The cool solution was then filtered and the precipitate washed with a 1 per cent solution of hydrochloric acid, dried at $130^{\circ}$ to $140^{\circ}$ C., and weighed. The total time required for the determination, including the drying and weighing, was about three hours, and the results represent what can be expected if determinations are made with no other precautions than the avoidance of sunlight. ${ }^{3}$ The errors (approximately 1 part per 1,000 in the precipitation of silver and 2 parts per 1,000 in the precipitation of hydrochloric acid) are what can be expected in standardizations of $0.1 \mathrm{~N}$ solutions, and are too large to be ignored in analyses that lay claim to accuracy.

The action of light always causes low results if silver chloride is formed by adding an excess of hydrochloric acid to a solution of silver; it always causes high results if silver chloride is formed by adding an excess of silver nitrate to a solution of hydrochloric acid or a chloride. The positive error is always greater than the negative for the same degree of exposure.

Both errors are caused by the decomposition of silver chloride. Little or none of the chlorine resulting from the decomposition

${ }^{3}$ For example, in one text it is stated: "Die ganze Operation der Silberbestimmung kann unbeschadet der Genauigkeit bei gewöhnlichen Tageslicht gemacht werden." 
escapes but is largely changed back into chloride ions. ${ }^{4}$ If hydrochloric acid is in excess, the chlorine resulting from the decomposition of silver chloride is not reprecipitated because no more silver ions are available. The error, therefore, is negative and represents the quantity of chlorine lost by the precipitate. If, however, the chloride ion is precipitated by an excess of silver nitrate, the chlorine resulting from the decomposition is reprecipitated as silver chloride. The error in this case is positive because some of the chloride ions precipitate more than one ion of silver. The positive error is further increased by the fact that the decomposition of silver chloride by light is accelerated by the presence of silver nitrate. ${ }^{5}$ If ideal conditions prevail the reactions might proceed until the excess of silver nitrate in solution would be exhausted. In this case the excess would determine the extent of the plus error. If exposure were continued after the excess of silver nitrate was used up, the precipitate would begin to lose weight, but never (assuming quantitative conversions) below the theoretical unless the weight of silver in the silver nitrate added in excess during the precipitation was less than the original weight of chlorine in the solution.

The results shown in Table 2 indicate that the effect of light on dry precipitates of silver chloride will cause only very small negative errors. These errors become greater if the dry precipitates are moistened and then exposed to the action of light. The effect of light seems to be still greater if the precipitates are filtered, washed, and exposed before drying. Precipitate No. 6, in Table 2, was washed with $100 \mathrm{ml}$ of water after it had been exposed to light, dried, and weighed. The washing caused a loss in weight of $0.3 \mathrm{mg}$ in addition to the $0.9 \mathrm{mg}$ previously lost. The washings showed no silver, but gave a faint test for chloride. The other precipitates in Table 2 lost no more than $0.1 \mathrm{mg}$ as a result of a similar washing after they had been exposed to light and dried.

\section{EXAMINATION OF THE PRECIPITATES FORMED UNDER THE INFLUENCE OF LIGHT}

All precipitates formed under the influence of light showed an increased weight if silver nitrate was in excess and a deficiency in weight when hydrochloric acid was in excess. It would be difficult to determine the composition of such precipitates by chemical analysis. In a precipitation of silver with an excess of hydrochloric acid under the influence of light a solution equivalent to $0.6985 \mathrm{~g}$ of silver chloride yielded only $0.6858 \mathrm{~g}$. No silver was left in the filtrate. When the precipitate was treated in a porcelain crucible with concentrated nitric acid and then repeatedly with hydrochloric acid to convert all silver to silver chloride, a final weight of $0.6983 \mathrm{~g}$ was obtained. This can be explained by assuming that the original precipitate consisted of a mixture of metallic silver and silver chloride and that

\footnotetext{
4 The conversion is not necessarily quantitative. For a discussion on the change of chlorine to chloride ions in dilute acid solutions under the influence of light, see A. J. Allmand, P. W. Cunliffe, and R. E. W. Maddison, J. Chem. Soc., 127, p. 822; 1925, and p. 655; 1927.

ऽ J. M. Eder, Ausführliches Handbuch der Photographie, 4, pt. 1, p. 12, 2d ed.; 1898.
} 
the treatment with nitric and hydrochloric acids converted all of the silver to chloride. ${ }^{6}$

In a precipitation of hydrochloric acid with an excess of silver nitrate under the influence of light a solution equivalent to $0.8887 \mathrm{~g}$ of silver chloride yielded $0.9232 \mathrm{~g}$. By treating this precipitate with concentrated nitric acid and then with hydrochloric acid in a porcelain crucible a final weight of $0.9342 \mathrm{~g}$ was obtained. If it is assumed that the original precipitate $(0.9232 \mathrm{~g}$ in weight) consisted of metallic silver and silver chloride, then the excess weight $(0.9232 \mathrm{~g}-0.8887 \mathrm{~g}$ or $0.0345 \mathrm{~g}$ ) should be the weight of metallic silver. This is equivalent to $0.0113 \mathrm{~g}$ of chlorine and should correspond to the increase in weight when the precipitate was treated with nitric and hydrochloric acids. The actual increase in weight was $0.9342 \mathrm{~g}-0.9232 \mathrm{~g}$ or $0.0110 \mathrm{~g}$.

Neither of these results definitely eliminates silver subchloride, $\mathrm{Ag}_{2} \mathrm{Cl}$, as a constituent of the precipitates. By working with thin films and a microbalance Hartung ${ }^{7}$ observed a decomposition of silver iodide under the influence of light amounting to as much as 90 per cent. Others ${ }^{8}$ have shown that from the standpoint of photography synthetic mixtures of colloidal silver and silver halides react the same as photohalides formed under the influence of light. Experiments Nos. 12, 13, 14, and 15, in Table 1, were performed to see whether the decomposition of silver chloride could be pushed beyond the point represented by the formula $\mathrm{Ag}_{2} \mathrm{Cl}$. In these tests so little silver chloride was involved that no precipitate settled from the cool opalescent solution until it had been exposed to the light for over five hours. The results show that almost all of the chlorine was lost, and indicate that metallic silver will finally be obtained if the particles of silver chloride are very small and the exposure is sufficiently prolonged.

\section{SUMMARY}

The experiments described in this paper show the direction and magnitude of the errors that may be expected in analytical work if silver chloride is not protected from light during precipitation, filtration, and drying. Exposure to light during precipitation always causes positive errors if silver is in excess and negative errors if hydrochloric acid is in excess. Light has very little effect on dry silver chloride. The error, if any, is negative and becomes greater if the dried precipitate is moistened before exposure. It is still greater if the precipitate is exposed without previous drying. The precipitate obtained during exposure to light probably consists of a mixture of metallic silver and silver chloride.

Washington, September 27, 1929.

\footnotetext{
6 In the preparation of silver phosphate, Baxter and Jones (see footnote 1, p. 110) observed that a.residue was left if the salt was dissolved in dilute nitric acid. This insoluble residue was greater in samples from which light was not excluded during the preparation. Analyses indicated that it was metallic silver.

7 E. J. Hartung, J. Chem. Soc., p. 1349; 1926.

8 Lüppo-Cramer Kolloidchemie und Photographie, 2d. ed.; 1921.
} 